\title{
Identification and expression of MMSA-8, and its clinical significance in multiple myeloma
}

\author{
RUI HE, NAN YANG, PENGYU ZHANG，JIE LIU，JUNHUI LI，FULIN ZHOU and WANGGANG ZHANG \\ Department of Clinical Hematology, Second Affiliated Hospital, Medical School of Xi'an Jiaotong University, \\ Xi'an, Shaanxi 710004, P.R. China
}

Received October 16, 2016; Accepted January 26, 2017

DOI: $10.3892 /$ or.2017.5609

\begin{abstract}
In our previous studies, we identified 12 multiple myeloma (MM)-associated antigens by serological analysis of tumor-associated antigens with a recombinant cDNA expression library (SEREX) on MM. MM-associated antigen-8 (MMSA-8) was one of the new antigens identified. We determined the 3'- and 5'-ends of MMSA-8 using SMART-rapid amplification of cDNA ends (RACE) and then cloned its full-length cDNA in the U266 cell line. The full cDNA sequence revealed that MMSA-8 is RPS27A-related transcript variant 1 that is specifically associated with MM. We examined its prognostic significance for the first time, by investigating the correlations between MMSA- 8 expression and definite clinicopathological features. We quantitatively assessed MMSA-8 expression using qRT-PCR and western blot analysis in healthy donors and MM patients. The expression levels of MMSA-8 were upregulated with statistical significance in MM patients in contrast to those in healthy donors. The expression of MMSA- 8 was also upregulated in relapsed patients compared with that in the complete remission (CR) group. Contrasting MMSA-8 expression levels in different patients with definite clinicopathological features suggested an association between MMSA- 8 with unfavorable clinicopathological characteristics, such as international staging system (ISS) stage III, higher lactate dehydrogenase (LDH) levels and higher C-reactive protein (CRP) levels. The expression of MMSA-8 was also increased in patients with unfavorable cytogenetic and genetic abnormalities, including the presence of $\mathrm{t}(11 ; 14), \mathrm{t}(4 ; 14), \mathrm{t}(14 ; 16), \operatorname{del}(17 \mathrm{p}), \operatorname{del}(13 \mathrm{q})$ and p53 deletion, which was statistically significant. The expression of MMSA-8 exhibited significant variance in the treatment responses of the $\mathrm{CR}, \mathrm{PR}$, progression and relapse groups. Univariate and multivariate analyses revealed that high
\end{abstract}

Correspondence to: Dr Wanggang Zhang, Department of Clinical Hematology, Second Affiliated Hospital, Medical School of Xi'an Jiaotong University, 157 West Five Road, Xi'an, Shaanxi 710004, P.R. China

E-mail: zhangwanggang2003@yahoo.com

Key words: multiple myeloma, hematologic malignancy, MMSA-8, RPS27A, p53
MMSA-8 values were associated with poorer progression-free survival (PFS) and overall survival (OS) in MM patients independently. In conclusion, our data indicated that MMSA-8 is an independent and unfavorable prognostic risk factor in MM; MMSA-8 is also a promising diagnostic and therapeutic target in MM patients, but further validation is needed.

\section{Introduction}

Multiple myeloma (MM), characterized by a heterogeneous clonal proliferation of plasma cells, is the second-most common hematological malignancy (1). MM is responsible for $15-20 \%$ of deaths from hematological malignancy (1). Targeted therapies such as the proteasome inhibitor (PI) bortezomib (Bz), the immunomodulatory drugs (IMiDs) lenalidomide and thalidomide (Th) have vastly improved the prognosis of MM patients (2-4). Unfortunately, MM is a heterogeneous disease with various disease courses, responses to therapy and survival outcome, and many patients still have to face challenges from disease progression (DP) and eventually succumb to MM (5). Thus, research to identify novel therapeutic agents is urgently needed. One promising area of recent investigation is the development of immunotherapies that target and eliminate myeloma cells more selectively (6-11). The premise of these therapies is the identification of cancer-specific and/or cancer-associated antigens (CAA) through the immune system. Moreover, finding an effective serological molecular marker which can forecast the prognoses and therapeutic responses of MM patients will be a valuable tool for MM therapy.

MM-associated antigen-8 (MMSA-8) (GenBank no. AY952889.1) is a new MM-associated antigen (MAA) that we previously identified. We serologically assessed tumor antigens using a recombinant cDNA expression library (SEREX) of MM to identify MM-associated antigens (MMSAs). MMSA-8 was confirmed as a new antigen that specifically interacted with the serum from patients with allogeneic myeloma but did not interact with normal donors (12). Differences in the MMSA-8 sequence with the novel available working version of the human genome suggests that MMSA-8 is a new RPS27Arelated transcription variant that is specifically associated with MM. The corresponding gene is human RPS27A, which is located on chromosome 2p16. RPS27A transcript variant 1, RPS27A transcript variant 2 and RPS27A transcript variant 3 are distinct transcripts of RPS27A, but they encode the same 
protein $(13,14)$. Further exploration of the correlation between MMSA-8 and RPS27A and of MMSA-8 expression patterns in MM thus became necessary. Therefore, the full-length cDNA sequence of MMSA-8 was cloned and its expression pattern was investigated in MM patients.

\section{Materials and methods}

Cell line culture. U266 cells were purchased from the Institute for Cancer Research of the Medical School of Xi'an Jiaotong University (China). The cells were cultured with RPMI-1640 medium (Gibco-BRL, Life Technologies Ltd., Paisley, Scotland) that was supplemented with $15 \%$ fetal bovine serum (FBS), $0.1 \mathrm{mg} / \mathrm{ml}$ streptomycin and $100 \mathrm{U} / \mathrm{ml}$ penicillin $\mathrm{G}$ and incubated at $37^{\circ} \mathrm{C}$ in a humidified atmosphere with $5 \% \mathrm{CO}_{2}$. Cells in a log phase of growth were used for all experiments.

Patients. Fifteen healthy hematopoietic stem cell transplant donors were obtained as controls. The donors and $85 \mathrm{MM}$ patients were enrolled in the study at the Department of Clinical Hematology of the Second Affiliated Hospital, Medical School of Xi'an Jiaotong University, between March 2011 and December 2014. Diagnoses were based on the 2008 World Health Organization criteria. The distribution of the clinical parameters and clinicopathological features of the patients are displayed in Table I. Protocols and response definitions were based on the 2011 MM Clinical Practice Guidelines of the National Comprehensive Cancer Network (NCCN) Clinical Practice Guidelines in Oncology. Patients received drugs, including Bz, Th, dexamethasone (D), vincristine (V), adriamycin (A) and prednisolone (P), in varying combinations. Thirty five patients used VAD $(\mathrm{V}+\mathrm{A}+\mathrm{D})$ regimens, 30 patients used $\mathrm{PD}(\mathrm{Bz}+\mathrm{D})$ regimens, 16 patients used a Th-Bz combination and 4 patients used PAD $(\mathrm{Bz}+\mathrm{A}+\mathrm{D})$ regimens combination as induction therapy. Th (100-200 mg) was taken orally each day during chemotherapy intervals. Most patients received a Th-P combination as maintenance therapy. Therapeutic responses were defined as complete remission (CR), partial remission (PR), progression or relapse. Follow-ups were performed on $68 \mathrm{MM}$ patients, and the $17 \mathrm{MM}$ patients were assessed at the first time of diagnosis and relapse. The duration of the median follow-up was 25.5 months, with a range of 5 to 45 months. All collected samples had the written informed consent of the subjects. The Ethics Committee of the School of Medicine of Xi'an Jiaotong University approved the study and all procedures were conducted in compliance with the Declaration of Helsinki.

Characterization of the MMSA-8 transcript using 3'- and 5'-RACE. To characterize the intact MMSA-8 transcript, 3'- and 5'- rapid amplification of cDNA ends (RACE) was performed using the SMARTer ${ }^{\mathrm{TM}}$ RACE cDNA Amplification kit (Clontech Laboratories, Inc., Mountain View, CA, USA) according to the manufacturer's instructions. The existing MMSA-8 sequences were used as a guide to design primers using Primer Premier 5.0 (12). Briefly, total RNA was isolated using TRIzol (Gibco-BRL, NY, USA). Total RNA (1 $\mu \mathrm{g})$ was used to generate 3 '- or 5'-RACE-ready cDNA using special primers, and associated reagents provided in the Moloney Murine Leukemia Virus (MMLV) reverse transcriptase kit.
The nested PCR reactions for 5'- and 3'-RACE began with primary $\mathrm{PCR}$, consisting of incubation at $95^{\circ} \mathrm{C}$ for $3 \mathrm{~min}$ before 33 cycles of denaturation at $94^{\circ} \mathrm{C}$ for $30 \mathrm{sec}$, annealing at $58^{\circ} \mathrm{C}$ for $30 \mathrm{sec}$, an extension at $72^{\circ} \mathrm{C}$ for $60 \mathrm{sec}$ and a reconditioning step at $72^{\circ} \mathrm{C}$ for $7 \mathrm{~min}$. Primary PCR was followed by secondary PCR, consisting of the same process as the primary PCR. The 3'- and 5'-RACE products were electrophoretically separated in a $1 \%$ agarose gel with $1 \mathrm{X}$ TAE buffer. The resulting bands were eluted with the Agarose Gel DNA Purification kit (Takara, Dalian, China) and were then cloned into the pGEM-T Easy vector (Promega, MI, USA). Four clone products from the same band were then sequenced. The DNA sequencing service was executed at Sangon Biological Engineering Technology and Service Co., Ltd. (Shanghai, China). Its corresponding primer pairs are listed in Table II.

Isolation and sequencing of MMSA-8 transcript. We used the sequences of the 3'- and 5'-RACE products of MMSA-8 as a guide for designing primers to isolate the full length sequence of MMSA-8. RT-PCR was performed with the High Fidelity Prime Script $^{\mathrm{TM}}$ RT-PCR kit (Takara). The product was electrophoretically separated in a $1 \%$ agarose gel with $1 \mathrm{X}$ TAE buffer. The resulting bands were cloned and the four clone products from each of the bands were then sequenced as previously described. Its corresponding primer pairs are listed in Table II.

Bioinformatics. Our newly cloned full-length sequences were then analyzed using Basic Local Alignment Search Tool (BLAST) search with GenBank at the NCBI. The potential coding sequences were validated with the open reading frame (ORF) finder of the NCBI.

Real-time quantitative PCR assay. Leukocyte cells were isolated from bone marrow samples using density gradient centrifugation with Ficoll-Hypaque. Total RNA was extracted from $1 \times 10^{6}$ leukocytes using TRIzol (Gibco-BRL, Gaithersburg, MD, USA). RNA quality was visually assessed by confirmation of intact 28 and $18 \mathrm{~S}$ ribosomal bands following agarose gel electrophoresis and ethidium bromide staining. cDNA was synthesized using the RevertAid First Strand cDNA synthase kit (Fermentas, Lithuania) according to the manufacturer's instructions. Primers for qRT-PCR were designed using Primer Premier 5.0 software. Human $\beta$-actin primers were used as an internal control. qRT-PCR was performed using the SYBR-Green PCR kit (Takara, Japan) according to the manufacturer's instructions on an ABI PRISM 7500 real-time PCR system. The following thermal cycling conditions were used: $95^{\circ} \mathrm{C}$ for $3 \mathrm{~min}$, followed by 40 cycles of $7 \mathrm{sec}$ at $95^{\circ} \mathrm{C}$ and $10 \mathrm{sec}$ at $57^{\circ} \mathrm{C}$. The qRT-PCR reactions were performed in total volumes of $20 \mu \mathrm{l}$ that contained $2 \mu \mathrm{l}$ of sample cDNA and $0.4 \mu \mathrm{M}$ of each primer. The resulting qRT-PCR products were 151 and $176 \mathrm{bp}$, respectively. The comparative CT method was used, and the data are presented as $2^{-\Delta \Delta C T}(15)$. Its corresponding primer pairs are listed in Table II.

Western blotting assay. Total protein was isolated and extracted with RIPA buffer (Pierce, Rockford, IL, USA) for $15 \mathrm{~min}$ on ice. Protein concentrations were detected using the BCA assay (Pierce). Blotted with specific anti-MMSA-8 
Table I. The expression rates and expression level of MMSA-8 with respect to the clinical characteristics of the MM cases.

\begin{tabular}{|c|c|c|c|c|c|c|}
\hline \multirow[b]{2}{*}{ Characteristics } & \multirow[b]{2}{*}{ Total, $\mathrm{N}=85$} & \multicolumn{2}{|c|}{ Expression rates of MMSA-8 } & \multirow[b]{2}{*}{ P-value } & \multirow[b]{2}{*}{$\begin{array}{c}\text { Expression level } \\
\text { of MMSA-8 }\end{array}$} & \multirow[b]{2}{*}{ P-value } \\
\hline & & $\begin{array}{c}\text { Positive } \\
n=60\end{array}$ & $\begin{array}{l}\text { Negative } \\
n=25\end{array}$ & & & \\
\hline Sex, female/male & $37 / 48$ & $28 / 32$ & $9 / 16$ & 0.473 & $40.05 / 50.68$ & 0.601 \\
\hline Age (years),$\geq 65 /<65$ & $20 / 65$ & $14 / 46$ & $6 / 9$ & 1.000 & $54.60 / 43.42$ & 0.569 \\
\hline \multicolumn{7}{|l|}{ ISS stage } \\
\hline I & 23 & 9 & 14 & 0.008 & 3.26 & $<0.001$ \\
\hline II & 39 & 29 & 10 & 0.042 & 39.90 & $<0.001$ \\
\hline III & 23 & 22 & 1 & $<0.001$ & 99.28 & $<0.001$ \\
\hline Isotype & & & & 0.578 & & \\
\hline igG & 42 & 31 & 11 & & 48.40 & 0.899 \\
\hline ig A & 26 & 18 & 8 & & 47.54 & \\
\hline igM & 11 & 7 & 4 & & 38.46 & \\
\hline $\operatorname{igE}$ & 1 & 1 & 0 & & 50.10 & \\
\hline Light chain & 5 & 3 & 2 & & 34.52 & \\
\hline \multicolumn{7}{|l|}{ Bone lesions } \\
\hline 0 & 24 & 16 & 8 & 0.383 & 44.18 & 0.294 \\
\hline $1-3$ & 36 & 28 & 8 & 0.261 & 58.13 & 0.092 \\
\hline$>3$ & 25 & 16 & 9 & 1.000 & 30.45 & 0.412 \\
\hline \multicolumn{7}{|l|}{ Renal failure } \\
\hline$(<2.0 / \geq 2.0 \mathrm{Scr} \mathrm{mg} / \mathrm{dl})$ & $74 / 11$ & $50 / 4$ & $24 / 7$ & 0.089 & $48.24 / 31.32$ & 0.323 \\
\hline $\mathrm{Hb}(>85 / \leq 85 \mathrm{~g} / \mathrm{l})$ & $68 / 17$ & $44 / 16$ & $24 / 1$ & 0.018 & $44.84 / 50.91$ & 0.229 \\
\hline $\begin{array}{l}\text { Calcium }(\mathrm{mg} / \mathrm{dl}) \\
(<12 / \geq 12)\end{array}$ & $69 / 16$ & $46 / 14$ & $25 / 2$ & 0.133 & $47.04 / 41.79$ & 0.609 \\
\hline $\mathrm{CRP}(\leq 10 />10 \mathrm{mg} / \mathrm{l})$ & $41 / 44$ & $24 / 36$ & $17 / 8$ & 0.031 & $17.83 / 72.35$ & $<0.001$ \\
\hline $\mathrm{LDH}(<250 / \geq 250 \mathrm{IU} / \mathrm{l})$ & $44 / 41$ & $23 / 37$ & $18 / 4$ & $<0.001$ & $15.43 / 78.91$ & $<0.001$ \\
\hline \multicolumn{7}{|l|}{ Cytogenetics } \\
\hline Absent & 28 & 10 & 18 & & 8.63 & \\
\hline Hyperdiploid & 6 & 4 & 2 & 0.202 (vs. absent) & 24.46 & 0.231 \\
\hline $\mathrm{t}(11 ; 14)$ & 8 & 7 & 1 & 0.016 (vs. absent) & 44.99 & 0.013 \\
\hline $\mathrm{t}(4 ; 14)$ & 3 & 3 & 0 & 0.064 (vs. absent) & 60.56 & 0.035 \\
\hline $\mathrm{t}(14 ; 16)$ & 3 & 3 & 0 & 0.064 (vs. absent) & 56.11 & 0.027 \\
\hline $\operatorname{del}(17 p)$ & 10 & 9 & 1 & 0.008 (vs. absent) & 72.81 & $<0.001$ \\
\hline $\operatorname{del}(13 q)$ & 15 & 15 & 0 & $<0.001$ (vs. absent) & 93.06 & $<0.001$ \\
\hline Double abnormalities & 6 & 6 & 0 & 0.006 (vs. absent) & 104.00 & $<0.001$ \\
\hline Not examined & 6 & & & & & \\
\hline \multicolumn{7}{|l|}{ p53 deletion } \\
\hline Absent & 71 & 49 & 22 & 0.098 & 40.60 & 0.001 \\
\hline Present & 8 & 8 & 0 & & 120.44 & \\
\hline Not examined & 6 & & & & & \\
\hline Myeloma cells $(<10 / \geq 10 \%)$ & $34 / 51$ & $18 / 42$ & $16 / 9$ & 0.007 & $8.35 / 71.19$ & $<0.001$ \\
\hline
\end{tabular}

MMSA-8, multiple myeloma-associated antigen-8; ISS, international staging system; CRP, C-reactive protein; LDH, lactate dehydrogenase.

primary $\mathrm{Ab}$ [anti-RPS27A antibody ab111598 (Abcam, Cambridge, MA, USA)]. Incubated in secondary antibody and then detected with enhanced chemiluminescence technique (Amersham Pharmacia Biotech). The protein values of MMSA- 8 and $\beta$-actin were quantified by Quantity One 4.2.2 Software (Bio-Rad, Hercules, CA, USA).
Statistical analysis. Mann-Whitney U tests and Fisher's exact test were used. Spearman correlation was used to detect the relationship between the expression value and levels of MMSA- 8 and the clinical parameters. The Kaplan-Meier method was used to calculate the progression-free survival (PFS) and overall survival (OS). Differences between survival 
Table II. Primers used in the study.

\begin{tabular}{lcl}
\hline Primer & Technique & Sequence 5'-3' \\
\hline RT primer & & TCTTGTGCTTATTCTTCTTGGGAGTGGTG \\
GSP1 & $5^{\prime}$-RACE & TTCCTTATCCTGGATCTTGGCCTTTACAT \\
GSP2 & $5^{\prime}$-RACE & AGAAAGAAGGTTAAGCTGGCTGTCCTGAA \\
GSP3 & $3^{\prime}$-RACE & CTTGGCCTTTACATTTTCTATCGTATCCG \\
GSP4 & 3'-RACE & GTGCTGGGGTGTTTATGGCAAGTCA \\
MMSA-8F & DNA-cloning & ATGTGGTGCTGGGGTGTTTAT \\
MMSA-8R & DNA-cloning & TTACTTGTCTTCTGGTTGGTGAAC \\
$\beta$-actinF & qPCR & TAGTTGCGTTACACCCTTTCTTG \\
$\beta$-actinR & qPCR & TCACCTTCACCGTTCCAGTTT \\
MMSA-8F & qPCR & ACCCTCGGATACGATAGAAAATG \\
MMSA-8R & qPCR & CACCACCACGAAGTCTCAACA
\end{tabular}

MMSA-8, multiple myeloma-associated antigen-8. RACE, rapid amplification of cDNA ends.
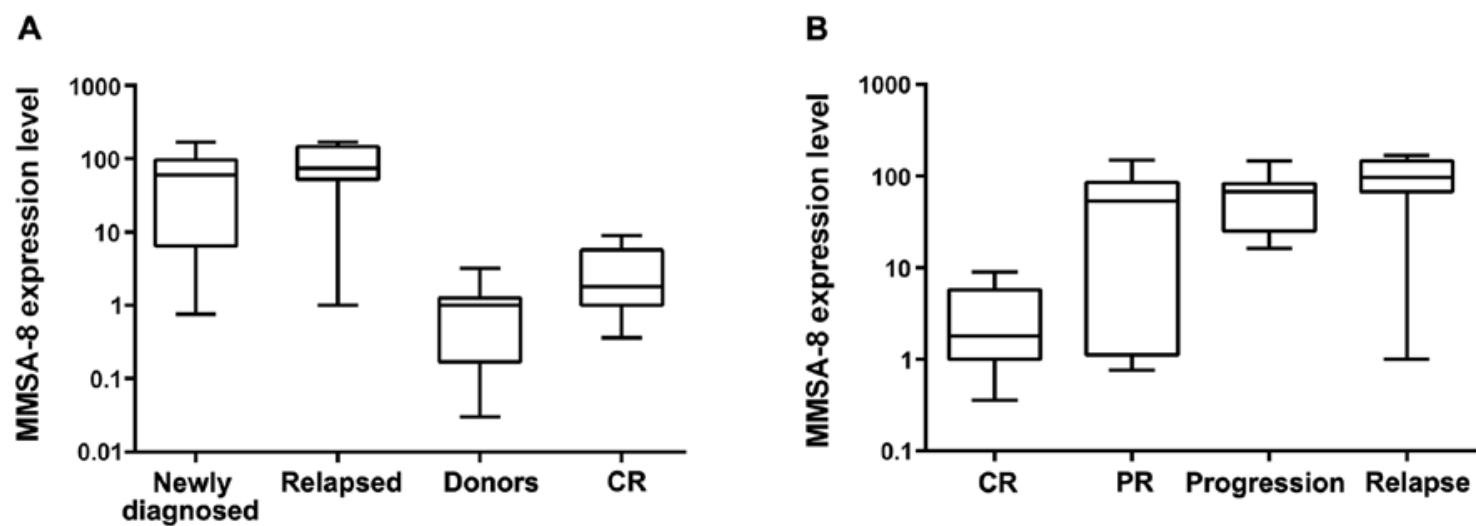

Figure 1. Comparison of MMSA-8 mRNA levels in MM patients. (A) Different MMSA-8 mRNA expression values using RT-PCR analysis in newly diagnosed, relapsed and CR groups and in healthy donor samples. (B) Different MMSA-8 mRNA expression levels in the CR, PR, progression and relapsed groups. Differences were significant, with $\mathrm{P}<0.001$ among different therapeutic responses. MM, multiple myeloma; MMSA-8, multiple myeloma-associated antigen-8; $\mathrm{CR}$, complete remission; PR, partial remission.

curves were analyzed using the log-rank test. With the Cox proportional hazards model, a multivariate analysis of survival time was performed to identify the adjusted impact of MMSA-8 overexpression on PFS and OS. The SPSS software package (SPSS17.0) was used for evaluation of statistical analyses and $\mathrm{P}<0.05$ was considered as statistically significant.

\section{Results}

Sequence analysis. The MMSA-8 sequence from the cDNA libraries may not represent full-length and/or mature transcripts. Therefore, we detected the 3'- and 5'-ends of MMSA-8 using SMART-RACE with the U266 cell line. We then performed RT-PCR to clone and confirm the new, full-length MMSA-8 cDNA sequence by primers that were designed using the newly obtained 3'- and 5'-RACE sequences from the U266 cell line. We did not detect other variants of MMSA- 8 in the U266 cells. Therefore, we identified a full-length MMSA-8 mRNA of 1,063 bp in the U266 cells via assembly of all the RACE and RT-PCR clones. We analyzed our sequence using BLAST search on GenBank of the NCBI. The corresponding mRNA was assigned as Homo sapien ribosomal protein S27a (RPS27A), transcript variant 1 (NCBI reference sequence: NM_002954.5). The cDNA sequence of MMSA-8 was $100 \%$ identical to RPS27A, transcript variant 1 . The corresponding gene was assigned as RPS27A [Homo sapien (human)] and gene ID: 6233. These results confirmed that MMSA-8 is RPS27A-related transcript variant 1 .

MMSA-8 expression in MM patients. MMSA-8 mRNA and protein levels were assessed in healthy donors and in newly diagnosed, relapsed and CR groups using qRT-PCR and western blotting. The mean relative value of MMSA-8 expressed in the control group was 9.10E-01. An MMSA-8 expression value that was one log grade higher than the expression value in the control group was defined as positive; lower values were considered to be negative. MMSA- 8 transcript levels revealed a striking increase in patients with DP (i.e., newly diagnosed or relapsed) relative to normal donors $(\mathrm{P}<0.001$ for both groups; Fig. 1A). Greater upregulation of MMSA-8 mRNA expression was observed in relapsed patients 

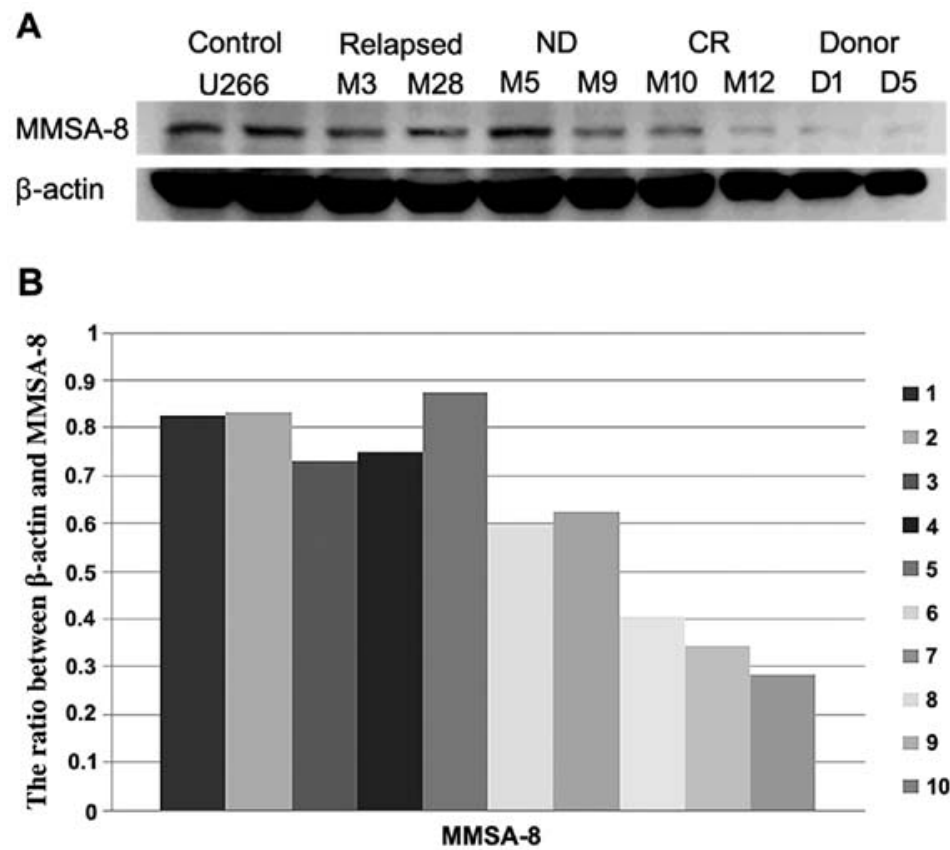

Figure 2. MMSA-8 protein in MM patients. (A) Western blot assay of MMSA-8 protein in samples from the ND, the relapsed MM and the CR groups and from healthy donors. $\beta$-actin levels suggest equal loading of all samples. (B) The ratio between $\beta$-actin and MMSA- 8 . MM, multiple myeloma; MMSA-8, multiple myeloma-associated antigen-8; ND, newly diagnosed; $\mathrm{CR}$, complete remission.
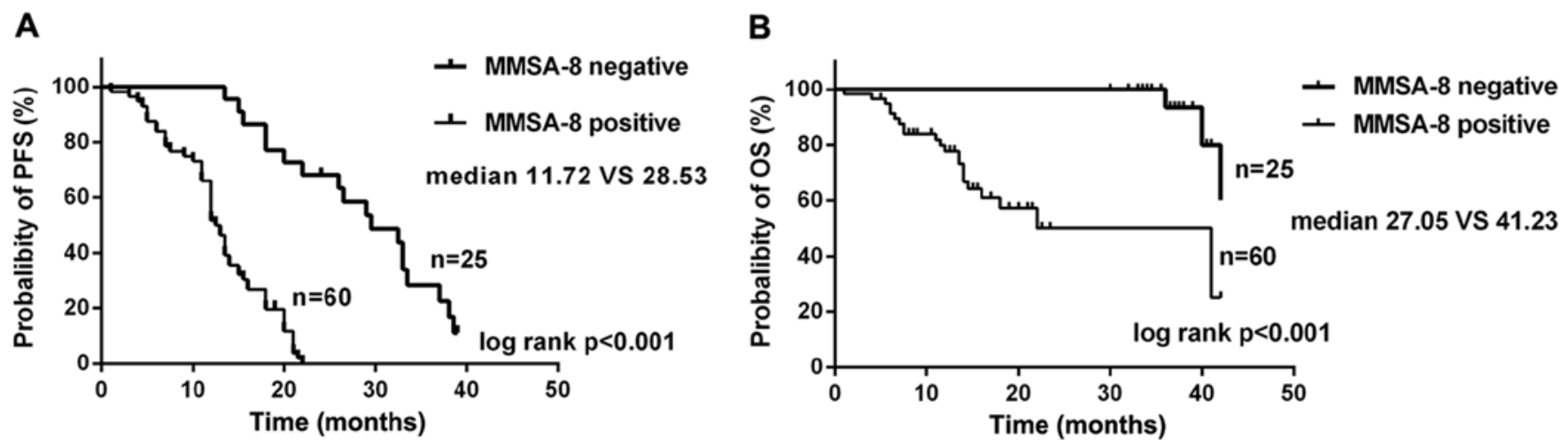

Figure 3. Relationship between the expression level of MMSA-8 and the patient survival outcome. (A) PFS in patients with MMSA-8-positive and with MMSA-8-negative expression. (B) OS in patients with MMSA-8-positive and with MMSA-8-negative expression. The differences were significant in both cases with $\mathrm{P}<0.001$ in A and B. MMSA-8, multiple myeloma-associated antigen-8, PFS, progression-free survival; OS, overall survival.

relative to the $\mathrm{CR}$ group $(\mathrm{P}<0.001$, Fig. $1 \mathrm{~A})$. There was also a significant statistical difference between healthy donors and the $\mathrm{CR}$ group ( $\mathrm{P}=0.03$; Fig. $1 \mathrm{~A})$. Western blot assay detected MMSA-8 protein in most MM patient samples (Fig. 2). $\beta$-actin expression was used as a loading control. A significant correlation was detected between MMSA-8 protein levels and MMSA-8 mRNA expression levels $(\mathrm{r}=0.813, \mathrm{P}<0.001)$ (data not shown).

Association of MMSA-8 expression levels with patient clinicopathological features. Table I presents the clinicopathological characteristics of the MM patients at diagnosis. The expression values of MMSA-8 were significantly correlated with international staging system (ISS) stage, myeloma cell burden, lactate dehydrogenase (LDH) and C-reactive protein (CRP) levels (Table I). The expression levels of MMSA- 8 were higher in patients with unfavorable cytogenetic abnormalities, including the presence of $t(11 ; 14), t(4 ; 14), t(14 ; 16)$, del(17p), $\operatorname{del}(13 q)$ and double abnormalities; this correlation was statistically significant (Table I). There were no significant relationships between mRNA expression of MMSA-8 and age, sex, immunoglobulin isotype, bone lesions, renal failure, anemia, hypercalcemia or hyperdiploid abnormalities (Table I).

Association of MMSA-8 expression with therapeutic response. The association of MMSA- 8 expression with treatment response was examined; treatment responses were classified as CR, PR, progression or relapse. The mean MMSA-8 levels were $5.11 \mathrm{E}+01$ in patients with $\mathrm{PR}, 6.58 \mathrm{E}+01$ in patients with DP and 9.93E+01 in patients with relapse. The three groups exhibited much higher MMSA-8 expression than the CR group $(\mathrm{P}=0.001, \mathrm{P}<0.001$ and $\mathrm{P}<0.001$, respectively; Fig. $1 \mathrm{~B})$. A significant difference between the $\mathrm{PR}$ and relapse groups was also found ( $\mathrm{P}=0.004$; Fig. 1B). 
Table III. Univariate analysis of PFS and OS in MM patients.

\begin{tabular}{|c|c|c|}
\hline \multirow[b]{2}{*}{ Variable } & \multicolumn{2}{|c|}{ P-value ${ }^{a}$} \\
\hline & PFS & OS \\
\hline $\begin{array}{l}\text { Sex } \\
\text { Female/male }\end{array}$ & 0.735 & 0.957 \\
\hline $\begin{array}{l}\text { Age (years) } \\
\geq 65 \text { vs. }<65\end{array}$ & 0.975 & 0.213 \\
\hline $\begin{array}{l}\text { ISS stage } \\
\text { I vs. II and III }\end{array}$ & $<0.001$ & $<0.001$ \\
\hline $\begin{array}{l}\text { Immunoglobulin isotype } \\
\operatorname{IgG} / \operatorname{IgA} / \operatorname{IgM} / \operatorname{IgE} / \text { light chain only }\end{array}$ & 0.665 & 0.905 \\
\hline $\begin{array}{l}\text { Bone lesions } \\
0 / 1-3 />3\end{array}$ & 0.579 & 0.584 \\
\hline $\begin{array}{l}\text { Renal failure }(\mathrm{Scr} \mathrm{mg} / \mathrm{dl}) \\
<2.0 \mathrm{vs} . \geq 2.0\end{array}$ & 0.742 & 0.745 \\
\hline $\begin{array}{l}\mathrm{Hb}(\mathrm{g} / \mathrm{l}) \\
>85 \text { vs. } \leq 85\end{array}$ & 0.499 & 0.253 \\
\hline $\begin{array}{l}\text { Hypercalcemia calcium (mg/dl) } \\
<12 \text { vs. } \geq 12\end{array}$ & 0.494 & 0.864 \\
\hline $\begin{array}{l}\mathrm{CRP}(\mathrm{mg} / \mathrm{l}) \\
\leq 10 \text { vs. }>10\end{array}$ & 0.004 & 0.012 \\
\hline $\begin{array}{l}\mathrm{LDH}(\mathrm{IU} / \mathrm{L}) \\
<250 \mathrm{vs} . \geq 250\end{array}$ & $<0.001$ & 0.002 \\
\hline $\begin{array}{l}\text { Myeloma cell burden }(\%) \\
\mathrm{t}(11 ; 14)\end{array}$ & $<0.001$ & $<0.001$ \\
\hline $\begin{array}{l}\text { Absent vs. present } \\
\mathrm{t}(14 ; 16)\end{array}$ & 0.909 & 0.908 \\
\hline $\begin{array}{l}\text { Absent vs. present } \\
\mathrm{t}(4 ; 14)\end{array}$ & 0.789 & 0.857 \\
\hline Absent vs. present & 0.568 & 0.917 \\
\hline $\begin{array}{l}\text { Hyperdiploid } \\
\text { Absent vs. present }\end{array}$ & 0.328 & 0.393 \\
\hline $\begin{array}{l}\operatorname{Del}(17 \mathrm{p}) \\
\text { Absent vs. present }\end{array}$ & 0.051 & 0.040 \\
\hline $\begin{array}{l}\operatorname{Del}(13 q) \\
\text { Absent vs. present }\end{array}$ & $<0.001$ & 0.028 \\
\hline $\begin{array}{l}\text { Double abnormalities } \\
\text { Absent vs. present }\end{array}$ & 0.028 & 0.055 \\
\hline $\begin{array}{l}\text { p53 deletion } \\
\text { Absent vs. present }\end{array}$ & $<0.001$ & 0.001 \\
\hline $\begin{array}{l}\text { MMSA-8 expression level } \\
\text { Negative vs. positive }\end{array}$ & $<0.001$ & $<0.001$ \\
\hline
\end{tabular}

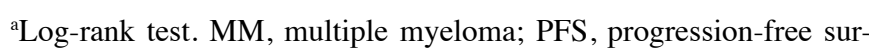
vival; OS, overall survival; ISS, international staging system; CRP, C-reactive protein; LDH, lactate dehydrogenase; MMSA-8, multiple myeloma-associated antigen-8.

Association of MMSA-8 expression with p53 deletion. Table I shows the prevalence of the p53 deletion in MM patients, as assessed using fluorescence in situ hybridization (FISH) at diagnosis. The p53 deletion was detected in 8 of the 79 patients, and all $8(100 \%)$ of the p53-deletion patients were positive for MMSA-8 expression. The positive MMSA-8 expression rates were lower in patients without p53 deletion (69.01\%), although this tendency was not statistically significant $(\mathrm{P}=0.098)$. The level of MMSA-8 expression was higher in groups with the p53 deletion than in groups lacking this genetic aberration; this tendency was statistically significant $(\mathrm{P}=0.001$; Table I).

Correlation of MMSA-8 expression with clinical outcome. The median duration of follow-up was 25.5 months, with a range of 5 to 45 months. MM relapsed and progressed in 29 patients, and therapeutic mortality was observed in 25 patients. The rates of OS and PFS were much lower in the MMSA-8-positive group (25\% OS and 0\% PFS) than in the MMSA-8-negative group (60\% OS and 11.4\% PFS, $\mathrm{P}<0.001$ for both; Fig. 3). Patients in the MMSA-8-positive group had a significantly shorter PFS (median 11.72 months) than patients in the MMSA-8-negative group (median 28.53 months, $\mathrm{P}<0.001$; Fig. 3A). The OS was significantly shorter (median 27.05 months) for patients in the MMSA-8-positive group than for patients in the MMSA-8-negative group (median 41.23 months, $\mathrm{P}<0.001$; Fig. 3B). With univariate risk factor analysis, including age, sex, ISS stage, immunoglobulin isotype, bone lesions, renal failure, $\mathrm{Hb}$, hypercalcemia, CRP, LDH, p53 deletion, myeloma cell burden, $\mathrm{t}(4 ; 14), \mathrm{t}(11 ; 14), \mathrm{t}(14 ; 16)$, del(17p), del(13q), double cytogenetic abnormalities and MMSA-8 expression level it was revealed that ISS stage, CRP, LDH, myeloma cell burden, del(17P), del(13q), double cytogenetic abnormalities, p53 deletion and MMSA-8 expression were significant (Table III). A multivariate analysis confirmed myeloma cell burden, p53 deletion and MMSA-8 expression level as risk factors for PFS and OS (Table IV).

\section{Discussion}

MMSA-8 is an MM-associated antigen that was identified by SEREX. The present study first determined the 3'- and 5'-ends of the MMSA-8 cDNA sequence in MM using SMART-RACE. The MMSA-8 cDNA sequence was fully concordant with RPS27A transcript variant $1(13,14)$. The RPS27A gene encodes a fusion protein comprised of ubiquitin (Ub) at the $\mathrm{N}$ terminus and ribosomal protein (RP) S27a at the C terminus. RPS27a is a ribosomal protein with a Ub C-terminal extension. The Ub-RPS27a precursor protein is rapidly processed by hydrolysis into an individual Ub monomer (16-18). RPS27a may perform extra-ribosomal functions in addition to its role in ribosome biogenesis and in post-translational protein modification. RPS27a is overexpressed in mouse liver cancer and in some human tumors (19-21). The exact extra-ribosomal function of RPS27a is not clear. Expression of RPS27a was increased in HMy 2 cells, PRMI8226 cells and U266 cells in the present study. RNA interference (RNAi) technology demonstrated that MMSA-8 downregulation inhibited U266 cell growth, increased cell apoptosis and the number of cells in the $\mathrm{S}$ phase. Our results suggest that MMSA-8 exerts a significant role in the generation and progression of MM.

This study investigated MMSA- 8 mRNA and protein expression in $\mathrm{MM}$ patients and normal donors, and its 
Table IV. Multivariate analysis of PFS and OS in MM patients.

\begin{tabular}{|c|c|c|c|c|}
\hline \multirow[b]{2}{*}{ Variables } & \multicolumn{2}{|r|}{ PFS } & \multicolumn{2}{|r|}{ OS } \\
\hline & P-value & RR $(95 \%$ CI $)$ & P-value & RR $(95 \%$ CI) \\
\hline $\begin{array}{l}\text { ISS stage } \\
\text { I vs. II and III }\end{array}$ & 0.051 & & 0.054 & \\
\hline \multicolumn{5}{|l|}{ CRP (mg/l) } \\
\hline$\leq 10$ vs. $>10$ & 0.354 & $1.385(0.696-2.758)$ & 0.274 & $0.479(0.128-1.792)$ \\
\hline \multicolumn{5}{|l|}{ LDH (IU/l) } \\
\hline$<250$ vs. $\geq 250$ & 0.785 & $1.109(0.529-2.323)$ & 0.357 & $0.546(0.151-1.978)$ \\
\hline Myeloma cell burden (\%) & 0.014 & $5.908(1.437-24.291)$ & 0.007 & $31.102(2.598-372.374)$ \\
\hline \multicolumn{5}{|l|}{$\operatorname{Del}(17 \mathrm{p})$} \\
\hline Absent vs. present & 0.107 & $1.919(0.869-4.241)$ & 0.200 & $2.288(0.645-8.113)$ \\
\hline \multicolumn{5}{|l|}{$\operatorname{Del}(13 q)$} \\
\hline Absent vs. present & 0.965 & $1.018(0.452-2.294)$ & 0.115 & $0.275(0.055-1.372)$ \\
\hline \multicolumn{5}{|l|}{ Double abnormalities } \\
\hline Absent vs. present & 0.729 & $1.190(0.445-3.180)$ & 0.056 & $5.761(0.955-34.747)$ \\
\hline \multicolumn{5}{|l|}{ P53 deletion } \\
\hline Absent vs. present & 0.008 & $3.775(1.410-10.102)$ & 0.001 & $12.851(2.948-56.017)$ \\
\hline \multicolumn{5}{|l|}{ MMSA-8 expression level } \\
\hline Negative vs. positive & $<0.001$ & $7.093(2.887-17.427)$ & 0.033 & $8.406(1.191-59.314)$ \\
\hline
\end{tabular}

PFS, progression-free survival; OS, overall survival; MM, multiple myeloma; ISS, international staging system; CRP, C-reactive protein; LDH, lactate dehydrogenase; MMSA-8, multiple myeloma-associated antigen-8; RR, risk ratio.

relationship with certain clinicopathological characteristics in prognosis. We detected that the expression levels of MMSA-8 were significantly upregulated in MM patients compared with those in normal donors and that relapsed patients exhibited a greater upregulation of MMSA-8 expression compared to the CR group. These results confirmed our previous hypothesis that MMSA- 8 expression is closely related to DP. The difference in the expression of MMSA- 8 in various characteristic groups indicated its unfavorable associated clinicopathological characteristics. Age, ISS stage, bone lesions and creatinine, $\mathrm{LDH}, \mathrm{CRP}, \mathrm{Hb}$ and calcium levels are independent prognostic factors of MM, and the present study indicated that patients in ISS stage III with higher LDH or CRP levels also had higher MMSA-8 expression levels (22-25). The MMSA-8 value was also higher in patients with unfavorable cytogenetic abnormalities, including the presence of $\mathrm{t}(11 ; 14), \mathrm{t}(4 ; 14), \mathrm{t}(14 ; 16)$, del(17p), $\operatorname{del}(13 q)$ and double abnormalities, and this association was statistically significant (26-30). However, there was no statistically significant association between MMSA-8 expression and age, anemia or hypercalcemia, thereby contradicting some previously published studies $(31,32)$. This discrepancy may be the result of the multiplicity and heterogeneity of myeloma cells in our studies (33). Positive MMSA-8 expression was associated with unfavorable clinical features at diagnosis. Strong evidence confirms that MMSA-8 is an unfavorable prognostic factor in MM. We also observed the lowest MMSA-8 mRNA expression level in the CR group, compared to patients with PR and DP. Relapsed patients exhibited the highest MMSA-8 expression, further supporting the hypothesis that MMSA-8 is a strong prognostic factor of response to therapy in $\mathrm{MM}$ patients.

Deletion of p53 was detected in 8 of the 79 patients in our study and was associated with increased MMSA- 8 mRNA levels, suggesting that MMSA-8 is related to p53 deletion. p53 is a tumor-suppressor gene that has been involved in the control of cell proliferation, differentiation, invasion and apoptosis (34). p53 gene deletions in $\mathrm{MM}$ are associated with poor patient survival $(28,35-37)$. As a direct transcriptional target of p53, the RPS27A gene is often overexpressed in response to DNA damage (38). RPS27a also interacts with MDM2 to suppress MDM2-associated p53 ubiquitination and then leading to the activation of p53 and cell cycle arrest (39). RPS27a may perform extra-ribosomal functions in addition to its role in ribosome biogenesis and post-translational protein modification $(40,41)$. Previously published research support our observations and conclusion, but the intrinsic mechanism involved in p53-RPS27a interactions requires further investigation (39).

We also analyzed the correlation between MMSA-8 expression and clinical outcome. The results demonstrated that the patients in the MMSA-8-positive group had lower rates of PFS and OS than the MMSA-8-negative patients. Patients with positive MMSA-8 expression also had significantly shorter PFS and OS. Univariate risk factor analysis found that ISS stage, CRP, LDH, myeloma cell burden, del(17P), del(13q), double cytogenetic abnormalities, p53 deletion and MMSA-8 expression were significantly significant. Multivariate analysis revealed that only the expression level of MMSA-8, p53 deletion and myeloma cell burden were independent risk 
factors in MM patients. These findings are consistent with previously published studies (42-44). However, we are the first to observe the relevance of the expression level of MMSA- 8 to patient survival.

In conclusion, the full-length cDNA sequence of MMSA-8 was cloned in MM and it was hypothesized that MMSA-8 is MM-associated RPS27A transcript variant 1. We firstly demonstrated the specific expression of MMSA- 8 in MM patients and the association of its dysregulation with unfavorable clinical features at diagnosis and poorer therapeutic outcome in MM. Univariate and multivariate analyses revealed that MMSA-8 may be an independent prognostic factor in MM. The present study supports further investigation to ascertain MMSA-8 as a promising diagnostic marker and therapeutic target in MM. Future studies should focus on its pathophysiological relevance in myeloma cells, especially with regard to its interaction with $\mathrm{p} 53$.

\section{Acknowledgements}

This study was supported by the National Natural Science Foundation of China (no. 81172257).

\section{References}

1. Group IMW; International Myeloma Working Group: Criteria for the classification of monoclonal gammopathies, multiple myeloma and related disorders: A report of the International Myeloma Working Group. Br J Haematol 121: 749-757, 2003.

2. Kumar SK, Rajkumar SV, Dispenzieri A, Lacy MQ, Hayman SR, Buadi FK, Zeldenrust SR, Dingli D, Russell SJ, Lust JA, et al: Improved survival in multiple myeloma and the impact of novel therapies. Blood 111: 2516-2520, 2008.

3. Pulte D, Gondos A and Brenner H: Improvement in survival of older adults with multiple myeloma: Results of an updated period analysis of SEER data. Oncologist 16: 1600-1603, 2011.

4. Brenner H, Gondos A and Pulte D: Expected long-term survival of patients diagnosed with multiple myeloma in 2006-2010. Haematologica 94: 270-275, 2009.

5. Kumar SK, Lee JH, Lahuerta JJ, Morgan G, Richardson PG, Crowley J, Haessler J, Feather J, Hoering A, Moreau P, et al International Myeloma Working Group: Risk of progression and survival in multiple myeloma relapsing after therapy with IMiDs and bortezomib: A multicenter international myeloma working group study. Leukemia 26: 149-157, 2012.

6. Tai YT, Li X, Tong X, Santos D, Otsuki T, Catley L, Tournilhac O, Podar K, Hideshima T, Schlossman R, et al: Human anti-CD40 antagonist antibody triggers significant antitumor activity against human multiple myeloma. Cancer Res 65: 5898-5906, 2005.

7. Bae J, Prabhala R, Voskertchian A, Brown A, Maguire C, Richardson P, Dranoff G, Anderson KC and Munshi NC: A multiepitope of XBP1, CD138 and CS1 peptides induces myeloma-specific cytotoxic T lymphocytes in T cells of smoldering myeloma patients. Leukemia 29: 218-229, 2015.

8. Rosenblatt J, Avivi I, Vasir B, Uhl L, Munshi NC, Katz T, Dey BR, Somaiya P, Mills H, Campigotto F, et al: Vaccination with dendritic cell/tumor fusions following autologous stem cell transplant induces immunologic and clinical responses in multiple myeloma patients. Clin Cancer Res 19: 3640-3648, 2013.

9. Hong S, Li H, Qian J, Yang J, Lu Y and Yi Q: Optimizing dendritic cell vaccine for immunotherapy in multiple myeloma: Tumour lysates are more potent tumour antigens than idiotype protein to promote anti-tumour immunity. Clin Exp Immunol 170: 167-177, 2012.

10. Anderson LD Jr, Cook DR, Yamamoto TN, Berger C, Maloney DG and Riddell SR: Identification of MAGE-C1 (CT-7) epitopes for T-cell therapy of multiple myeloma. Cancer Immunol Immunother 60: 985-997, 2011.

11. Michalek J, Ocadlikova D, Matejkova E, Foltankova V, Dudová S, Slaby O, Horvath R, Pour L and Hajek R: Individual myeloma-specific T-cell clones eliminate tumour cells and correlate with clinical outcomes in patients with multiple myeloma. Br J Haematol 148: 859-867, 2010.
12. Zhou FL, Zhang WG, Chen G, Zhao WH, Cao XM, Chen YX, Tian W, Liu J and Liu SH: Serological identification and bioinformatics analysis of immunogenic antigens in multiple myeloma. Cancer Immunol Immunother 55: 910-917, 2006.

13. Lamesch P, Li N, Milstein S, Fan C, Hao T, Szabo G, Hu Z, Venkatesan K, Bethel G, Martin P, et al: hORFeome v3.1: A resource of human open reading frames representing over 10,000 human genes. Genomics 89: 307-315, 2007.

14. Gonzalez-Begne M, Lu B, Han X, Hagen FK, Hand AR, Melvin JE and Yates JR: Proteomic analysis of human parotid gland exosomes by multidimensional protein identification technology (MudPIT). J Proteome Res 8: 1304-1314, 2009.

15. Schmittgen TD and Livak KJ: Analyzing real-time PCR data by the comparative C(T) method. Nat Protoc 3: 1101-1108, 2008.

16. Redman KL and Rechsteiner M: Identification of the long ubiquitin extension as ribosomal protein S27a. Nature 338: 438-440, 1989.

17. Shabek N and Ciechanover A: Degradation of ubiquitin: The fate of the cellular reaper. Cell Cycle 9: 523-530, 2010.

18. Komander D, Clague MJ and Urbé S: Breaking the chains: Structure and function of the deubiquitinases. Nat Rev Mol Cell Biol 10: 550-563, 2009.

19. Adams SM, Sharp MG, Walker RA, Brammar WJ and Varley JM: Differential expression of translation-associated genes in benign and malignant human breast tumours. Br J Cancer 65: 65-71, 1992.

20. Wong JM, Mafune K, Yow H, Rivers EN, Ravikumar TS, Steele GD Jr and Chen LB: Ubiquitin-ribosomal protein S27a gene overexpressed in human colorectal carcinoma is an early growth response gene. Cancer Res 53: 1916-1920, 1993.

21. Kanayama H, Tanaka K, Aki M, Kagawa S, Miyaji H, Satoh M, Okada F, Sato S, Shimbara N and Ichihara A: Changes in expressions of proteasome and ubiquitin genes in human renal cancer cells. Cancer Res 51: 6677-6685, 1991.

22. Vincent Rajkumar S: Multiple myeloma: 2014 update on diagnosis, risk-stratification, and management. Am J Hematol 89: 999-1009, 2014.

23. Tarkun P, Atalay F, Atesoglu EB, Mehtap O, Simsek M, Terzi E, Geduk A, Balli F, Batman A, Baydemir C, et al: Treatment of patients with multiple myeloma over 65 yr: More tolerability or better response? Eur J Haematol 94: 424-430, 2015.

24. Chim CS, Sim J, Tam S, Tse E, Lie AK and Kwong YL: $\mathrm{LDH}$ is an adverse prognostic factor independent of ISS in transplant-eligible myeloma patients receiving bortezomib-based induction regimens. Eur J Haematol 94: 330-335, 2015.

25. Kiba T, Ito T, Nakashima T, Okikawa Y, Kido M, Kimura A, Kameda K, Miyamae F, Tanaka S, Atsumi M, et al: Bortezomib and dexamethasone for multiple myeloma: Higher AST and LDH levels associated with a worse prognosis on overall survival. BMC Cancer 14: 462, 2014.

26. Tricot G, Barlogie B, Jagannath S, Bracy D, Mattox S, Vesole DH, Naucke $S$ and Sawyer JR: Poor prognosis in multiple myeloma is associated only with partial or complete deletions of chromosome 13 or abnormalities involving 11q and not with other karyotype abnormalities. Blood 86: 4250-4256, 1995.

27. Fonseca R, Barlogie B, Bataille R, Bastard C, Bergsagel PL, Chesi M, Davies FE, Drach J, Greipp PR, Kirsch IR, et al: Genetics and cytogenetics of multiple myeloma: A workshop report. Cancer Res 64: 1546-1558, 2004.

28. Fonseca R, Blood E, Rue M, Harrington D, Oken MM, Kyle RA, Dewald GW, Van Ness B, Van Wier SA, Henderson KJ, et al: Clinical and biologic implications of recurrent genomic aberrations in myeloma. Blood 101: 4569-4575, 2003.

29. Facon T, Avet-Loiseau H, Guillerm G, Moreau P, Geneviève F, Zandecki M, Laï JL, Leleu X, Jouet JP, Bauters F, et al; Intergroupe Francophone du Myélome: Chromosome 13 abnormalities identified by FISH analysis and serum beta2-microglobulin produce a powerful myeloma staging system for patients receiving high-dose therapy. Blood 97: 1566-1571, 2001.

30. Oh S, Koo DH, Kwon MJ, Kim K, Suh C, Min CK, Yoon SS, Shin HJ, Jo DY, Kwak JY, et al; Korean Multiple Myeloma Working Party (KMMWP): Chromosome 13 deletion and hypodiploidy on conventional cytogenetics are robust prognostic factors in Korean multiple myeloma patients: Web-based multicenter registry study. Ann Hematol 93: 1353-1361, 2014.

31. Kyrtsonis MC, Maltezas D, Tzenou T, Koulieris E and Bradwell AR: Staging systems and prognostic factors as a guide to therapeutic decisions in multiple myeloma. Semin Hematol 46: 110-117, 2009. 
32. Younes M,Hachfi H,Hammouda F, Younes K, Ben Hammouda S Jguirim M, Zrour S, Béjia I, Touzi M and Bergaoui N: Survival prognosis factors in multiple myeloma. Tunis Med 92: 399-405, 2014 (In French).

33. Lohr JG, Stojanov P, Carter SL, Cruz-Gordillo P, Lawrence MS, Auclair D, Sougnez C, Knoechel B, Gould J, Saksena G, et al; Multiple Myeloma Research Consortium: Widespread genetic heterogeneity in multiple myeloma: Implications for targeted therapy. Cancer Cell 25: 91-101, 2014.

34. Levine AJ: p53, the cellular gatekeeper for growth and division. Cell 88: 323-331, 1997.

35. Drach J, Ackermann J, Fritz E, Krömer E, Schuster R, Gisslinger H, DeSantis M, Zojer N, Fiegl M, Roka S, et al: Presence of a p53 gene deletion in patients with multiple myeloma predicts for short survival after conventional-dose chemotherapy. Blood 92: 802-809, 1998.

36. Königsberg R, Zojer N, Ackermann J, Krömer E, Kittler H, Fritz E, Kaufmann H, Nösslinger T, Riedl L, Gisslinger H, et al: Predictive role of interphase cytogenetics for survival of patients with multiple myeloma. J Clin Oncol 18: 804-812, 2000.

37. Chang H, Qi C, Yi QL, Reece D and Stewart AK: p53 gene deletion detected by fluorescence in situ hybridization is an adverse prognostic factor for patients with multiple myeloma following autologous stem cell transplantation. Blood 105: $358-360,2005$
38. Nosrati N, Kapoor NR and Kumar V: DNA damage stress induces the expression of ribosomal protein S27a gene in a p53-dependent manner. Gene 559: 44-51, 2015.

39. Sun XX, DeVine T, Challagundla KB and Dai MS: Interplay between ribosomal protein S27a and MDM2 protein in p53 activation in response to ribosomal stress. J Biol Chem 286: 22730-22741, 2011.

40. Warner JR and McIntosh KB: How common are extraribosomal functions of ribosomal proteins? Mol Cell 34: 3-11, 2009.

41. Wool IG: Extraribosomal functions of ribosomal proteins. Trends Biochem Sci 21: 164-165, 1996.

42. Gertz MA, Lacy MQ, Dispenzieri A, Greipp PR, Litzow MR, Henderson KJ, Van Wier SA, Ahmann GJ and Fonseca R: Clinical implications of $\mathrm{t}(11 ; 14)(\mathrm{q} 13 ; \mathrm{q} 32), \mathrm{t}(4 ; 14)(\mathrm{p} 16.3 ; \mathrm{q} 32)$, and $-17 \mathrm{p} 13$ in myeloma patients treated with high-dose therapy. Blood 106: 2837-2840, 2005.

43. van de Donk NW and Sonneveld P: Diagnosis and risk stratification in multiple myeloma. Hematol Oncol Clin North Am 28: 791-813, 2014.

44. Mangiacavalli S, Pochintesta L, Cocito F, Pompa A, Bernasconi P, Cazzola M and Corso A: Correlation between burden of 17P13.1 alteration and rapid escape to plasma cell leukaemia in multiple myeloma. Br J Haematol 162: 555-558, 2013. 